にデータベースに収録されているので，キーワードの付 与が完全であれば直ちに検索され利用される論文であ る。

\section{7. 追記}

Agric. Biol. Chem. の論文の揭戴を BIOSIS PREVIEWS(冊子体では Biological Abstracts/RRM) で調 查した結果表 8 に示したように相当数が採択されている. BAに収録された件数と合計すると，Agric. Biol. Chem. の全報文の 95〜98\% は 2 誌に収録されている. 1984 年
の 19 件は Agric. Biol. Chem. 48 巻 1 号の Notes の 12 件中 8 件, Short Communications 7 件中 6 件, 同 2 号の Notes 4 件, Rapid Paper 1 件で方り, Notes その他はすべて BIOSIS に収録されていることが判明し た.この抄録誌には抄録はない。

なお農化誌の論文は全部で 3 件のみが収録され， 54 巻 11 号, 56 巻 4 号の 2 篇の計 3 篇すべてノートであっ た.

「化学と生物」は収録さ机ていない。 （筑波大学応用生物化学系 山中 啓）

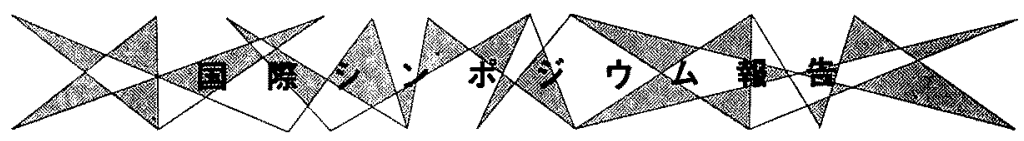

\section{フラビンおよびフラビン蛋白質に関する}

\section{第 8 回国際シンポジウムに出席して}

3年ごとに開かれてきた標題のシンポジウム (International Symposium on Flavins and Flavoproteins) 舞台をイギリスに移し，グレートブリテン島最南端の中 心都市ブライトン (Brighton) にあるサセックス大学 (University of Sussex) E未いて, R. C. Bray 教授がチ ェアマンとなって，士る7月8日より13 日亦で行加 t.

本シンポジムはビタミン $\mathrm{B}_{2}$ とその誘導体(フラ ビン) 怙よびフラビン蛋白質 (醉素) を研究する者の semiclosed な集りで，今回の参加者は総勢 195 名（米 国 64, 英国 36, 西独 25 名，㴗加であった。、日本か らは，組織委員として山野俊雄(阪大医教授) 括上び八 木國夫（応用生化研，名大名誉教授）の両先生が加市 り，19名の参加者方放ったが，農芸化学関係からは筆者 一人であった。

本ンンポジウムの形態は, 前回〔祥雲弘文氏, 本誌, 55，1048（1981）乱よび，筆者，蛋白質核酸酵素， 27,2019 (1982) 参照]と変らず，午前中は総括講演， 午後はポスターによる研究発表, そして，多食をはさん で, 薄暮の 8 時から 10 時 15 分までディスカッション リーダーを中心とした，その日のポスターによる発表内 容の総合討論女質疑から成る全体会議で掅成され，亦 た，遅い夜のとばりのなかで夜半まで酒を飲みながらの
研究情報の交換は有意義なものであった。

総括諢演は, 最近のフラビン化合物和よびフラビン蛋 白質の研究動向を示寸もので，主として演者の研究を中 心に周辺をレビューするというのが主なものであった が，今回は，あらかじめディスカッションリーダーに送 付しておいた発表要旨より，20 分間の口頭発表を許さ れた者が数人おり，会議に新味をもたせた。

Bray 教授の開会宣言のあと, V. Massey (Michigan 大・アメリカ）教授が最初の演者となり「化学反応性を 持つフラビン化合物による活性中心檴造の探究」と題し 講演した（写真 1).内容の詳細は Proceedings (eds. Bray, R. C., Engle, P.C., and Mayhew, S. G., Walter de Gruyter \& Co., Berlin 上り出版予定）に譲るが, 佊らのグループが, 現在, 精力的に推し進めているプロ ジェクトで，イソアロキサジン環の $2^{\prime}, 4^{\prime}, 7^{\prime}$ あいは $8^{\prime}$ などを各種原子（団）で置換したフラビン誘導体と種々 のアポ蛋白質とから再構成された醉素の性質より，活性 中心の楧造を知万らとするるのであり，莫大なデーター に裏打された広範困の酵素に関する知見は全フラビノ口 ジストの垂ぜんの的であった。

今回のシンポジウムの特徽をあけると, 初めて, フラ ビン酵素を対象とした遗伝子のクローニングに関する実 験デ一タが発表されたことではないたるらか。すなわ ち, J.R. Guest $と$ D. W. Rice (Sheffield 大・イギリス) は「E. coliフラビン蛋白質の研究に対する分子遺伝学 的アプローチ」と題し，二人で請演し，フラビン蛋白質 の構造と機能を解析する手段として遗伝子のクローニン 


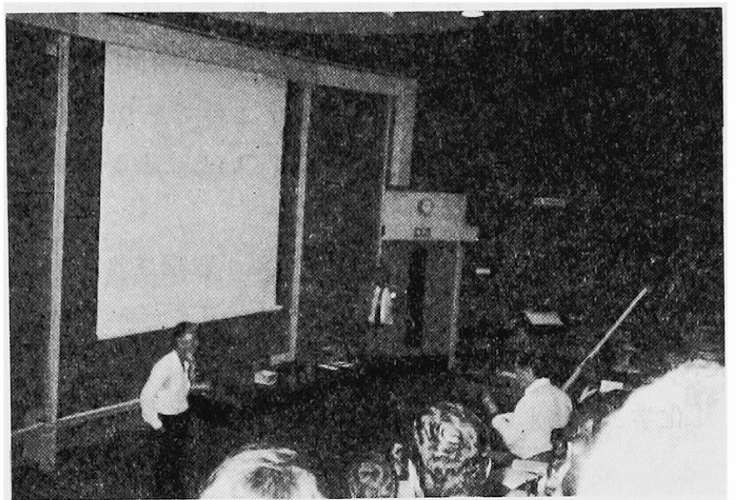

写真 1 V. Massey 教授(左)の発表に対 L, F. Müll （農業大・オランダ）教授 (右) が質問しているとこ ろ, 中央で立っているのは座長の C. Veeger（農業 大・オランダ) 教授.

グが有効であることを説いた．また，一方，T. O. Baldwin (Texas A\&M 大・アメリカ) は「微生物ルシフェ ラーゼ遺伝子のクローニングと酵素の完全一次構造」と 題し, Vibrio harveyi といら海水中の発光バ テリアの ルシフェラーゼ $(\alpha, \beta$ の 2 本のサブユニットから成る) の遺伝子を $E$. coli RR 1 に組み込み, 見事, 大腸菌を 発光させることに成功した成果を示した．遗伝子のク口 ーニングとは若干趣を異にするが, M. S. Jorns (Hahnemann 大・アメリカ) は「大腸菌 DNA フォートリアー ゼの研究：DNA 修復におけるフラビンの役割」と題 し，熱弁をふるい，正常な菌では細胞 1 個当り 10〜20 コピー程度しか含まれない DNA フォートリアーゼを 過剩生産するフォートリアーゼ過剩生産性プラスミドを 持つ変異株を分離し, 菌体蛋白質の $15 \%$ に及ぶフォー トリアーゼを生産させることに成功し，これより精製し た酵素の性質を報告した.

以上のようなトピックスと並行し，フラビンおよびフ ラビン蛋白質の古くて新しい話，すなわち，古くから提 起されている問題であるが完全な結論を得るに至ってい ない多くのナゾ（たとえば，酸素の活性化機構，脱水素 機構, 電子移動 (CT 中間体) 機構など) に迫る講演が あったが,ここでは割愛する.この他, 最近進境著しい フラビンの体内代謝に関する講演 [八木國夫（応用生化 研・日本)]哺乳動物におけるリボフラビンの代謝, およ び, D. B. McCormick (Emory 大・アメリカ) フラビン の哺乳類に打ける代謝）などが行われた.

一方, ポスターセッションの発表件数は3日間で, 138 件を数完， 1 日 2 会場（午後 2 時ころから 4 時半こ

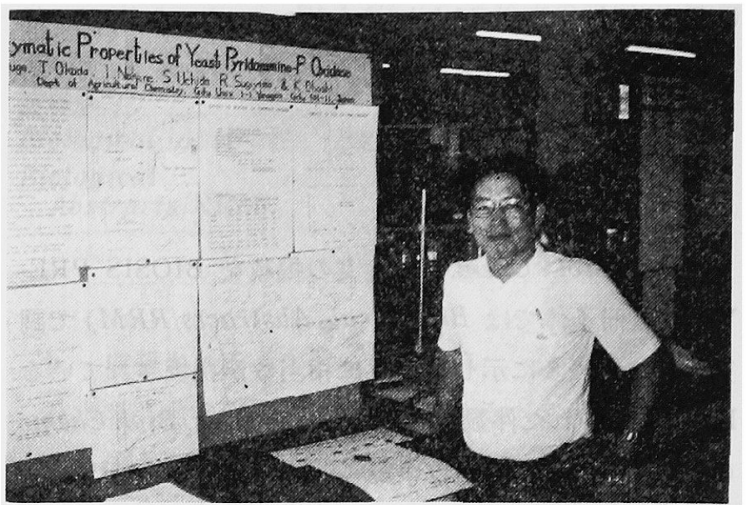

写真 2 ポスター展示場の一風景（写真の人物は筆 者).

ろまで）に 40 件以上の発表が行放れ，それぞれを吟味 しながら見て回るのは到底不可能な仕事であり，勢い興 味のある発表のみを読むということになった，とくに， 今回のポスター展示会場は, 化学実験室で実験用のスタ ンドにパネルを固定したもので（写真 2)，発表内容を 精查しょらにも場所的ゆとりがなく大変苦労した.

発表された研究内容を材料を主として分類してみる $\xi$, acyl CoA reductase $\zeta$ electron transfer flavoprotein (ETF) および芳香族化合物の hydroxylase でとも に 13 件と多く, 次いで, Mo 含有フラビン酵素（主に xanthine oxidase) で 12 件, D-amino acid oxidase 8 件などが多い材料といえる.今回，とくに多かった題材 は, lipoamide dehydrogenase (8件)に関するものであ

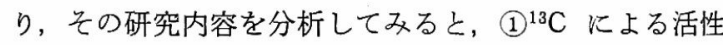
中心の探究 (2)基質アナログによる不活性化 (3)活性中心 に存在する His 残基周辺のアミノ酸配列 (4)(部分) 一次 構造の決定 (5) X線回折 (6)ピルビン酸脱水素酵素複合体 中での様態 (7)in vitro における生合成 (8)ステロイド生 合成系における $\mathrm{NADH}$ 再生系としての利用, でありバィ オテクノロジーへの応用も発表された。 また，今回はじ めて話題になったフラビン蛋白質として, 白色木材腐巧 菌 Sporotrichum pulverulentum の cellobiose oxidoreductase [F.F. Morpeth (Reading 大・イギリス)]があ る.

午前中の会場であった円形階段講義室は 250 ～300 人 収容の音響効果の優れた施設で, 最後列からでもマイク なしで十分講演を聴き取れたが，惜しむらくは，机と椅 子が極端に低く，さして高くない犼れわ机本人でも長 時間の講義は苦痛に感じた.むして, 背丈の高い欧米人 
は，滕を大きく折り曲げて聴いており，窮屈そうであっ た、また，前記したように，ポスター展示場は，化学実 験室であり、散然と置かれたガラス器具や実験道具には 少々うんざりした.

な括，次回は，D. B. McCormick (Emory 大・アくり) カ)がチェアマンとなり，1987 年にアトランタで開催さ れることが，7月11 日夕刻，古くから伝わる Michelham 修道院のバーン (ブライトンの東方 $20 \sim 30 \mathrm{~km}$ の
ところにある）で行われた晚さん公て発裴され，全員の 拍手で迎点られた。

また，12 日の年後には CT (charge transfer) カップ と銘打った親善サッカー試合も行われたが，日本人の参 加者はなかった。

最後に, 今回のシンポジゥム出席に刘し御援助いただ いた(貾)農芸化学研究奖励会に深く感謝いたします。

(岐皁大学费学部 柘植治人) 